\title{
KAITAN ASPEK STATUS SOSIAL PETANI SAYUR TERHADAP JENIS SUMBER INFORMASI YANG DIMANFAATKAN DI KELURAHAN LINGKAR SELATAN KECAMATAN JAMBI SELATAN KOTA JAMBI
}

\author{
Nida Kemala, Wiwin Alawiyah \\ Fakultas Pertanian Universitas Batanghari Jambi \\ Email : nidakemala@yahoo.com
}

\begin{abstract}
This research had been held in Lingkar Selatan Village which focusing to learn the description of social status of farmer, information source that used by them and the relationship between those variables. Social status were indikated in three cases e.g. education, land wide and the respodent role in its siciety. There were 41 samples that selected by simple random sampling method. Description method was used to analyzed those variables and Chi-Square $2 \times 2$ was applied to analyzed the relationship between them.

The result of this research should be expected to be a foundation in deciding by the authority in selecting a agricultural information transfer system which considered the various information sources. Instead of this consideration the information should be correctly transferred. The result of this research showed that the farmer number that has low education category (63\%) was higher than the high one (37\%). The low category of land wide was dominant (66\%). Only three farmers that had authority role and all of them had showed hight category of information source useness. It showed 59\% (24 farmers) have hight category of information source useness while $41 \%$ (17 farmers) showed low category of it useness and 16 farmers not used electronic information source yet. The farmer authority showed a significant relationship with information source useness, while education dan land wide had no relationship significantly with it.
\end{abstract}

\section{Keyword : Social Status, Extension, Information source, Farmer}

\section{PENDAHULUAN}

Saat ini konsumsi sayuran Indonesia diperkirakan baru mencapai $70 \%$ dari jumlah yang dianjurkan standar internasional untuk masyarakat sehat gizi ( \pm 150 gram/kapita/hari). Sayuran yang berwarna hijau gelap merupakan sayuran yang paling kaya akan vitamin A dan zat besi (Sutarya, 1995). Luas tanam sayuran terbesar berada di Kecamatan Jambi Selatan yaitu 130 hektar tetapi masih memiliki produktivitas terendah $(0,16 \mathrm{Ton} / \mathrm{Ha})$. (Dinas Pertanian dan Tanaman Pangan Kota Jambi 2015). Sedangkan luas tanam terbesar di Kecamatan Jambi Selatan ditunjukkan oleh Kelurahan Lingkar Selatan yaitu $40 \mathrm{Ha}$ (Dinas Pertanian Tanaman 2015).

Dalam hal ini dapat dinyatakan bahwa kemajuan sub-sektor hortikultura berkaitan dengan kuantitas dan kualitas informasi yang diterima oleh petani. Sedangkan kualitas informasinya tergantung dari jenis sumber informasi yang dimanfaatkan oleh petani. Dalam hal ini menurut Koentjaraningrat (1990) 
pengetahuan seseorang akan mempengaruhi cara dan tingkah laku seseorang dalam bertindak, dan hal ini tergantung dari besarnya pengetahuan yang dimiliki orang tersebut. Untuk itu sumber informasi sangat berpengaruh terhadap pengetahuan petani. Lebih lanjut Khaeruddin (1992) menyatakan bahwa kurangnya pengetahuan petani terkait dengan terbatasnya pendidikan yang dimiliki oleh para petani. Oleh sebab itu para petani yang mempunyai tingkat pendidikan yang memadai dapat lebih awal memberikan respon terhadap permasalahan ataupun kegiatan dalam masyarakat.

Adanya televisi dan radio merupakan media yang baik dan cepat untuk menyampaikan pesan. Selain televisi dan radio sumber informasi dapat berasal dari media massa, tetangga, teman, petugas penyuluhan pertania, pedagang, pejabat desa atau dari informasi lainnya. Semakin beragamnya informasi yang diperoleh petani, memungkinkan petani lebih baik lagi dalam menjalankan usahataninya, karena dengan pengetahuan yang cukup petani dapat memilah mana informasi yang sesuai untuk usahataninya (Van Den Ban, 1999).

Dalam memperoleh informasi petani biasanya dipengaruhi oleh beberapa hal diantaranya yaitu status sosial seseorang dalam masyarakat. Status sosial berpengaruh dalam mendapatkan informasi pertanian dari berbagai sumber informasi yang ada. Petani yang mempunyai status sosial lebih tinggi akan lebih banyak dan lebih berbobot dalam mendapatkan informasi pertanian dari berbagai sumber, dan memiliki berbagai aset untuk mendapatkan berbagai sumber informasi, hal ini sebaliknya dengan petani yang status sosial lebih rendah.

Petani mendapatkan informasi pertanian cenderung dipengaruhi oleh status sosialnya seperti tingkat kesejahteraan petani, status dan luas kepemilikan tanah, pendidikan formal petani dan pekerjaan seseorang dalam struktur organisasi masyarakat. Hanya sedikit petani yang berhubungan langsung dengan penyuluh atau peneliti, hal ini disebabkan oleh kedudukan sosial petani dalam masyaarakat yang berbeda-beda. Van Den Ban (1999) menyebutkan bahwa petani biasanya paling banyak belajar dari sesama petani. Karena itulah petani yang juga inovator dalam memperkenalkan sistem usahatani baru merupakan sumber informasi yang penting bagi petani lain.

Menurut Soekartawi (1995) status sosial ditentukan dalam berbagai faktor seperti : tingkat kesejahteraan petani, status dan luas kepemilikan tanah, tingkat pendidikan dan kedudukan seseorang dalam masyarakat. Tingkat kesejahteraan berpengaruh dalam memperoleh jenis informasi, status sosial sering membentuk pola komunikasi di dalam sistem sosial.

Seseorang dalam masyarakat terkadang memiliki beberapa kedudukan status sosial sekaligus tetapi masyarakat hanya melihat pada kedudukan utama yang menonjol, atas itu yang bersangkutan digolongkan dalam kelas-kelas tertentu dalam masyarakat (Soekanto 1994). Perbedaan status sosial petani akan menyebabkan perbedaan dalam mendapatkan informasi pertanian sebab ini petani yang memiliki status sosial yang lebih tinggi akan lebih mudah dalam mendapatkan informasi pertanian dari berbagai sumber yang ada, sedangkan petani yang memiliki status sosial yang lebih rendah cenderung akan lebih sulit dalam mendapatkan informasi pertanian dari berbagai sumber. Oleh karena itu peneliti tertarik untuk meneliti dengan kajian "Hubungan status sosial terhadap jenis informasi yang dimanfaatkan petani sayur di Kecamatan Lingkar Selatan Kota Jambi” 


\section{RUMUSAN MASALAH}

Berdasarkan hal tersebut, permasalahan yang dapat dirumuskan adalah:

1. Bagaimana gambaran status sosial petani dan karakteristik sumber informasi yang dimanfaatkan di Kelurahan Lingkar Selatan?

2. Apakah aspek status sosial petani berkaitan dengan jenis informasi yang dimanfaatkan petani di Kelurahan Lingkar Selatan?

\section{Tujuan Penelitian}

Penelitian ini dilakukan dengan tujuan untuk mengetahui :

1. Gambaran status sosial petani sayur dan karakteristik sumber informasi yang dimanfaatkan petani sayur di Kelurahan Lingkar Selatan.

2. Kaitan aspek status sosial petani sayur dengan jenis informasi yang dimanfaatkan petani di Kelurahan Lingkar Selatan.

\section{LANDASAN TEORI}

\section{Usahatani Sayur}

Setiap jenis sayuran menghendaki keadaan yang sesuai untuk pertumbuhannya. Ada yang hanya dapat tumbuh dan berproduksi dengan baik pada ketinggian dan kisaran suhu tertentu (Rahadi, 1995). Berdasarkan ketinggian dari permukaan laut dan kisaran suhu, sayuran dibedakan atas sayuran dataran rendah dan sayuran dataran tinggi. Jenis sayuran dapat tumbuh baik ditempat yang berhawa panas maupun berhawa dingin, sehingga dapat diusahakan di ke-2 daerah tersebut. Ketinggian ideal untuk tanaman sayuran adalah 100-500 m dpl.

Tanaman sayuran juga tahan terhadap air hujan sehingga dapat ditanam sepanjang tahun pada musim kemarau, jika penyiraman dilakukan dengan teratur dan dengan air yang cukup tanaman dapat tumbuh sebaik musim penghujan. Jika budidaya sayuran di dataran tinggi tanaman ini tidak perlu air yang banyak sebaliknya jika ditanam di dataran rendah diperlukan air yang banyak (Haryanto dkk, 1995). Kegiatan usahataninya meliputi proses pengolahan tanah, pembibitan, penyemaian, penanaman, pemeliharaan serta panen. Dengan teknik yang benar akan didapat hasil yang memuaskan baik kualitas maupun kuantitas.

\section{Jenis Informasi Pertanian}

Ragam sumber informasi akan sangat membantu petani dalam memperoleh informasi. Sumber ini dapat berasal dari media massa, tetangga, petugas penyuluh pertanian, pedagang, pejabat desa atau informan yang lain. Bagi petani yang baru belajar berinovasi maka pelayanan penyuluhan pertanian terhadapnya adalah merupakan sumber informasi yang sangat penting. Menurut Purwoko (1994), sumber informasi dapat dikelompokkan menjadi tiga kelompok yaitu sumber informasi tertulis, sumber informasi lisan dan sumber informasi elektronik.

Sumber Informasi Lisan. Berbagai informasi lisan banyak digunakan petani dalam mengelola usahataninya. Van Den Ban (1999) menyebutkan biasanya petani banyak belajar dari sesama petani. Petani biasanya berbagi informasi dan bertukar pengalaman antar sesama petani. Hal ini dilakukan karena petani biasanya lebih dekat dengan sesama petani bila dibandingkan dengan penyuluh atau agen pemerintahan lainnya. Walaupun ada juga sebagian petani yang memanfaatkan sumber informasi lisan yang lain seperti dinas pemerintahan, dosen pertanian, pedagang pertanian, kelompok tani, konsultan pertanian dan kursus atau pelatihan pertanian. 
Sumber Informasi Tertulis. Kata yang tertulis, tergambar atau tercetak merupakan sumber informasi yang efektif. Meski masih banyak petani yang buta huruf dan belum mengenal bacaan tetapi dalam penggunaan bahan cetakan ini sangat penting untuk memperoleh informasi. Menurut Van Den Ban, (1999) petani yang baru mengenal huruf memerlukan bahan bacaan yang sederhana dan mudah dimengerti, sehingga informasi yang terkandung di dalamnya akan sampai kepada petani dengan cepat. Sumber informasi tertulis ini meliputi surat kabar/koran, majalah, paper, makalah, data survei, artikel, jurnal dan publikasi departemen pertanian (buku petunjuk praktis, leaflet, bulletin dan brosur).

Sumber Informasi Elektronik. Selain mendapatkan informasi dari sumber informasi tertulis dan lisan, petani juga mendapatkan informasi dari media elektronik. Van Den Ban (1999) menyatakan bahwa radio merupakan media massa paling penting bagi petani di negara berkembang. Program pedesaan untuk pembangunan pertanian, harus disiarkan ketika petani dan keluarganya dapat mendengarkan. Biasanya pada pagi hari sebelum kesawah atau sore hari setelah selesai berkerja.

\section{Konsep Adopsi Inovasi}

Menurut Mardikanto (1993), adopsi dalam proses penyuluhan pertanian, pada hakekatnya dapat diartikan dalam proses penyuluhan perilaku baik yang berupa pengetahuan (cognitive), sikap (affective), maupun keterampilan (psyhomotoric) pada diri seseorang telah menerima inovasi yang disampaikan penyuluh kepada masyarakat sasarannya.

Proses komunikasi pertanian adalah kompleks, disebabkan karena banyaknya faktor yang terlibat di dalamnya, walaupun proses komunikasi pertanian kelihatannya sederhana yaitu hubungan antara komunikator dengan komunikan namun karena keduanya berada dalam lingkup dan lingkungan yang beda, sehingga di dalam proses tersebut banyak aspek yang terlibat. Proses komunikasi dijelaskan sebagai suatu proses yang panjang, karena pada akhirnya dala,m proses tersebut diharapkan agar komunikan berubah fungsinya menjadi komunikator dalam proses komunikasi selanjutnya. Dengan kata lain bahwa di dalam proses komunikasi pertanian itu harus mampu melahirkan calon-calon adopter. Menurut Roger dalam Mardikanto (1993) menyebutkan bahwa setiap kelompok masyarakat terbagi menjadi 5 (lima) kelompok individu berdasarkan tingkat kecepatan mengadopsi inovasi, yaitu 2,5\% kelompok perintis (innovator), 13,5\% kelompok pelopor (early adopter), 34,0 \% kelompok penganut diri (early majority), 13,5\% kelompok penganut lambat (late majority), dan 2,5\% kelompok orang-orang kolot/naluri (laggard).

\section{Hubungan Status Sosial terhadap Jenis Sumber Informasi Pertanian yang Dimanfaatkan oleh Petani}

Selain faktor pribadi, faktor lain yang mempengaruhi pemanfaatan sumber informasi adalah status sosial. Menurut Soekanto (1994), status sosial merupakan kedudukan seseorang (individu) dalam suatu kelompok pergaulan hidupnya . Di lain pihak Soekanto (1994), menyatakan bahwa status soial merupakan tempat seseorang secara umum dalam masyarakatnya sehubungan dengan orang-orang lain, dalam arti lingkungan pergaulannya, prestasinya dan hak serta kewajibannya. Status sosial akan menentukan tingkat kredibilitas seseorang dalam melakukan komunikasi pertanian. Hal ini berarti status sosial akan mempengaruhi petani dalam memperoleh dan memanfaatkan sumber informasi yang ada. Status sosial 
ditentukan oleh berbagai faktor antara lain yaitu tingkat kesejahteraan petani, pendidikan, status dan luas pemilikan tanah, pekerjaan dan kedudukan dalam sturuktur kekuasaan yang dalam masyarakat.

\section{Tingkat pendidikan}

Tingkat pendidikan adalah sarana belajar yang akan menanamkan pengertian sikap yang mengutamakan menuju penggunaan praktek pertanian yang lebih modern. Sehingga penyerapan informasi akan lebih cepat dimengerti oleh petani. Hal ni akan membentuk status seseorang. Sumber daya manusia memegang peran penting dalam pengembangan ilmu pengetahuan dan teknologi guna menunjang pembangunan. Karena kemampuan petani dan keputusan yang diambil mengenai pelaksanaan usahatani, begitu menentukan bagi kecepatan pembangunan, maka program khusus untuk pendidikan petani merupakan segi penting dari pendidikan untuk pembangunan.

\section{Kedudukan seseorang dalam struktur organisasi masyarakat}

Seseorang yang bekerja sebagai pegawai atau ulama biasanya mempunyai status sosial yang tinggi bila dibandingkan dengan seseorang yang bekerja sebagai buruh kasar dan bukan pegawai negeri atau yang mempunyai kedudukan dalam masyarakat. Kedudukan seseorang dalam masyarakat yang dimaksud adalah pekerjaan seseorang menyangkut pemimpin dan bukan pemimpin baik sebagai pemimpin formal maupun non formal yang mempunyai pengaruh dan wewenang dalam memimpin. Menurut Soekanto (1994) adanya kekuasan cenderung tergantung dari hubungan antara pihak yang memiliki kemampuan untuk melancarkan pengaruh dengan pihak lain yang menerima pengaruh itu rela atau karena terpaksa, apabila kekuasaan dijelmakan pada diri seseorang biasanya orang itu dinamakan pemimpin. Hipotesis

Dalam mencari atau memanfaatkan informasi pertanian, petani banyak dipengaruhi oleh beberapa faktor. Salah satunya adalah status sosial. Perbedaan status sosial ini menyebabkan perbedaan dalam mendapatkan informasi pertanian. Status sosial yang tinggi akan memudahkan seseorang dalam mendapatkan informasi, sebaliknya status sosial yang rendah. Kedekatan petani dengan penyuluh yang berstatus sosial tinggi, akan berbeda dengan petani yang status sosialnya rendah sehingga akan mempengaruhi jumlah informasi yang diterima petani.

Petani yang status sosialnya tinggi tidak akan sungkan menanyakan hal baru kepada penyuluh atau instansi pemerintah yang lain. Hal ini akan menyebabkan perbedaan informasi yang diterima petani sehingga akan menyebabkan perbedaan hasil usahatani yang diperoleh.

Dari uraian di atas uraian maka dapat dirumuskan hipotesis bahwa diduga status sosial petani sayur berkaitan dengan jenis sumber informasi yang dimanfaatkan di Kecamatan Jambi Selatan.

\section{Output yang Diharapkan}

Prospek dari hasil penelitian ini diupayakan agar menjadi dasar pertimbangan pihak terkait (pemerintah, instansi penyuluh, dll) dapat menentukan strategi penyampaian informasi pertanian dengan memprioritaskan penggunaan jenis sumber informasi yang secara optimal dapat digunakan sebagai sarana penyampaian berbagai informasi yang berkaitan dengan pengembangan sektor pertanian khususnya sub-sektor hortikulltura. Dengan demikian diharapkan informasi sampai tepat pada sasarannya. 


\section{METODE PENELITIAN}

Ruang Lingkup Penelitian

Penelitian ini dilaksanakan di Kelurahan Lingkar Selatan dengan pertimbangan bahwa daerah ini merupakan sentra produksi sayuran terbesar di Kota Jambi. Penelitian ini difokuskan pada kajian gambaran status sosial petani sayur, jenis sumber informasi yang dimanfaatkan dan kaitan antar ke dua variabel tersebut.

\section{Metode Pengumpulan dan Sumber Data}

Penelitian ini menggunakan metode survei yang menurut Silalahi, U (2010), survei ini diartikan sebagai suatu usaha untuk mendapatkan dan mengumpulkan data dan informasi dari berbagai sumber. Dalam hal ini sebagai sumber data primer adalah petani sayur, dengan teknik pengumpulan data secara observasi, wawancara dan pengisian kuisioner yang terpola dan terstruktur sesuai dengan kebutuhan akan data yang mengacu pada topik penelitian. Sumber data sekunder diperoleh dari literatur-literatur dan instansi-instansi terkait.

\section{Metode Penarikan Sampel}

Tasri, E., S. (2007), menyatakan sampel adalah kumpulan unit sampling yang merupakan subset dari populasi. Selanjutnya Winarno,S dalam Tasri E, S (2007), menyatakan bahwa bila populasi cukup homogen, terhadap populasi di bawah 100 dapat digunakan sampel sebesar 50\% dan bila populasi diatas 100 maka besarnya sampel sebesar 15\%. Berdasarkan pertimbangan uraian di atas maka diambil sampel sebesar 50\% (41 RTP) dari total populasi petani (82 RTP), secara acak sederhana (simple random sampling).

\section{Metode Analisis Data}

Data dianalisis secara deskriptif dan untuk mengetahui kaitan status sosial petani dengan pemanfaatan jenis sumber informasi diuji dengan alat statistik non parametik yaitu Chi-Square $2 \times 2$ (Sugiyono,2004) dengan rumusan sebagai berikut:

$$
\begin{array}{lc}
\mathrm{X}^{2} & \mathrm{n}\{[\mathrm{ad}-\mathrm{bc}]-\mathrm{n} / 2)\}^{2} \\
= & (\mathrm{a}+\mathrm{c})(\mathrm{b}+\mathrm{d})(\mathrm{c}+\mathrm{d})(\mathrm{a}+\mathrm{b})
\end{array}
$$

\section{Dimana :}

$\mathrm{X}^{2} \quad$ : Chi kuadrat hasil perhitungan

a-d : Frekuensi dari kombinasi dua

kategori

n : Jumlah sampel

$\mathrm{X}^{2}$ tabel : 3,841 $\left(\mathrm{X}^{2}\right.$ pada $\alpha=0,05$ dan

Db. k-1)

Tabel 3. Model Analisis Uji Chi-Square dengan Kontingensi 2x2

$$
\text { Pemanfaatan Jenis }
$$

Var. Yang Sumber Informasi Jumlah

\begin{tabular}{lccc}
\multicolumn{1}{c}{ diteliti } & Tinggi & Rendah & \\
\hline Kategori 1 & $\mathrm{a}$ & $\mathrm{b}$ & $(\mathrm{a}+\mathrm{b})$ \\
Kategori 2 & $\mathrm{c}$ & $\mathrm{d}$ & $(\mathrm{c}+\mathrm{d})$ \\
Jumlah & $(\mathrm{a}+\mathrm{c})$ & $(\mathrm{b}+\mathrm{d})$ & $\mathrm{n}$ \\
\hline
\end{tabular}


Hipotesis statistik adalah sebagai berikut :

Ho: $X^{2}=0$

Hi : $X^{2} \neq 0$

\section{Kaidah keputusan :}

Nilai $X^{2}$ tabel dengan derajat bebas $(d b)=1$ pada tingkat kepercayaan $95 \%$ adalah 3,85. Dalam pengujian $X^{2}$ hitung dibanding dengan $X^{2}$ Tabel dengan ketentuan sebagai berikut :

1. Terima $\mathrm{H}_{0}$ jika nilai $\mathrm{X}^{2}$ hitung $\leq \mathrm{X}^{2}$ tabel

2. Tolak $\mathrm{H}_{0}$ jika nilai $\mathrm{X}^{2}$ hitung $>\mathrm{X}^{2}$ tabel

\section{Konsep Pengukuran Variabel}

Pengertian dan batasan operasional yang digunakan dalam penelitian ini adalah sebagai berikut:

1. Status sosial adalah kedudukan seseorang sehubungan dengan orang lain dalam arti lingkungannya, presentasenya dan hak serta kewajibannya, yang diukur dari :

a. Pendidikan: yaitu pembelajaran yang didapat secara formal yang pernah diikuti petanisayur dengan kategori:

Tinggi : pendidikan petani $\geq$ SLTP

Rendah : pendidikan petani < SLTP

b. Luas lahan yaitu luasnya lahan yang digarap oleh petani dengan kategori :

Tinggi : Luas $\geq$ Rata-rata luas lahan

Rendah : Luas $\leq$ Rata-rata luas lahan

c. Kedudukan seseorang yaitu menyangkut pekerjaan seseorang sebagai pemimpin dan bukan pemimpin baik formal maupun non formal yang dipandang mempunyai pengaruh dan wewenang terhadap lingkungannya dengan kategori:

Tinggi : bila seseorang sebagai pemimpin baik formal maupun non formal yang mempunyai kemampuan untuk menggerakan masyarakat sekitarnya.

Rendah : apabila seseorang bukan sebagai pemimpin baik formal maupun non formal atau anggota masyarakat tidak mempunyai pengaruh dan wewenang.

2. Pemanfaatan sumber informasi yaitu dilihat dari mana petani mendapatkan jenis informasi pertanian yaitu dari :

a. Sumber informasi lisan yaitu dari mana petani mendapatkan informasi pertanian dari PPL, pedagang, sesama petani dan lain-lain.

b. Sumber informasi tulisan yaitu informasi dari Koran, majalah atau publikasi departemen pertanian dan lain-lain

c. Sumber informasi media elektronik yaitu dimana petani mendapatkan informasi pertanian dari media elektronik seperti televisi, radio,internet dan lain-lain.

kategori jenis sumber informasi adalah sebagai berikut :

Tinggi : Bila memanfaatkan $\geq 5$ jenis sumber informasi

Rendah : Bila memanfaatkan $<5$ jenis sumber informasi 


\section{HASIL DAN PEMBAHASAN}

\section{Gambaran Umum Daerah Penelitian}

\section{a. Letak Geografis}

Kelurahan Lingkar Selatan terletak di Kecamatan Jambi Selatan Kota Jambi. Kelurahan ini berjarak dari pusat pemerintahan kelurahan sebagai berikut : $6 \mathrm{~km}$ ke pemerintahan kecamatan, $7 \mathrm{~km}$ ke pemerintahan kabupaten, $7 \mathrm{~km}$ ke ibukota kabupaten dan $14 \mathrm{~km}$ ke ibukota provinsi. Secara administratif memiliki batasbatas wilayah sebagai berikut:

- Batas utara : Muaro Jambi

- Batas selatan : Paal Merah

- Batas barat : Paal Merah

- Batas timur : Paal Merah

b.Keadaan Penduduk Menurut Kelompok Umur dan Jenis Kelamin

Jumlah penduduk di Kelurahan Lingkar Selatan Tahun 2015 adalah 16.151 jiwa (8.341 laki-laki, 7.81 perempuan). Penduduk berdasarkan kelompok umur dapat dilihat pada Tabel 4.

Tabel 4

Jumlah Penduduk Kelurahan Lingkar Selatan Berdasarkan Kelompok

Umur Tahun 2016

\begin{tabular}{lccc}
\hline No. & $\begin{array}{c}\text { Kel. Umur } \\
\text { (Tahun) }\end{array}$ & $\begin{array}{c}\text { Jumlah } \\
\text { Penduduk } \\
\text { (Jiwa) }\end{array}$ & $\begin{array}{c}\text { Persentase } \\
(\%)\end{array}$ \\
\hline 1. & $0-1$ & 162 & 1,00 \\
2. & $1-4$ & 776 & 4,8 \\
3. & $5-6$ & 533 & 3,31 \\
4. & $7-14$ & 1.897 & 11,74 \\
5. & $15-56$ & 9.819 & 60,80 \\
6. & $56<$ & 2.964 & 18,35 \\
& Jumlah & 16.151 & 100 \\
\hline
\end{tabular}

Sumber : Monografi Kelurahan Lingkar Selatan, 2015

Tabel 4 menunjukkan bahwa wilayah penelitian didominasi oleh penduduk yang produktif (15-56 tahun) yaitu sebesar 9.819 jiwa $(60,80 \%)$ dan balita $(0-1$ tahun) menempati jumlah terendah yaitu $1 \%$ (162 jiwa). Dengan demikian wilayah ini masih berpotensi untuk tetap berkarya.

c. Keadaan Penduduk Menurut Mata Pencaharian

Mata pencaharian penduduk cukup beragam dapat dilihat pada Tabel 5. 
Tabel 5

Jumlah Penduduk Kelurahan Lingkar Selatan Menurut Mata Pencaharian Tahun 2016

\begin{tabular}{llcc}
\hline No. & $\begin{array}{c}\text { Jenis Mata } \\
\text { Pencaharian }\end{array}$ & $\begin{array}{c}\text { Jumlah } \\
\text { Penduduk } \\
(\mathbf{K K})\end{array}$ & $\begin{array}{c}\text { Persentase } \\
(\boldsymbol{\%})\end{array}$ \\
\hline 1. & Buruh & 3.245 & 20,09 \\
2. & Petani & 1.541 & 9,54 \\
3. & Peternak & 934 & 5,78 \\
4. & Pedagang & 301 & 1,86 \\
5. & Pegawai Negeri & 197 & 1,22 \\
6. & Pegawai Swasta & 223 & 1,38 \\
7. $\quad$ Pengusaha & 85 & 0,53 \\
8. Dan lain-lain & 9.625 & 59,59 \\
Jumlah & 16.151 & 100 \\
\hline
\end{tabular}

Sumber : Monografi Kelurahan Lingkar Selatan Tahun, 2015

Berdasarkan Tabel 5, terlihat mayoritas mata pencaharian penduduk adalah buruh $(20,09 \%)$. Kemudian penduduk dengan mata pencaharian petani dan peternak sebanyak $15.32 \%$. Sedangkan mata pencaharian terendah adalah penduduk sebagai pengusaha $(0,53 \%)$.

\section{d. Keadaan Penduduk Menurut Tingkat Pendidikan}

Kualitas penduduk tergantung pada tingkat pendidikan dan di Kelurahan Lingkar Selatan terdapat beberapa sarana pendidikan seperti yang dapat dilihat pada Tabel 6. Tabel 6 menunjukkan bahwa mayoritas penduduk berpendidikan SD (1.200 jiwa atau sebesar 38,66\%) diikuti dengan SMP (1.079 siswa atau sebesar $34,77 \%$ ) sedangkan tingkat pendidikan yang paling bawah adalah Pondok Pesantren yaitu 36 siswa atau $1,16 \%$.

Tabel 6

Tingkat Pendidikan di Kelurahan Lingkar Selatan Tahun 2016

\begin{tabular}{llcc}
\hline No. & \multicolumn{1}{c}{$\begin{array}{c}\text { Nama } \\
\text { Sekolah }\end{array}$} & $\begin{array}{r}\text { Jumlah } \\
\text { Siswa } \\
\text { (Jiwa) }\end{array}$ & $\begin{array}{c}\text { Persentase } \\
(\%)\end{array}$ \\
\hline 1. & Sekolah Dasar & 1.200 & 38,66 \\
2. & SMP & 1.079 & 34,77 \\
3. SMA & 789 & 25,41 \\
4. Pondok Pesantren & 36 & 1,16 \\
Jumlah & 3.104 & 100 \\
\hline
\end{tabular}

Sumber : Monografi Kecamatan Lingkar Selatan Tahun, 2015

\section{e. Keadaan Sarana dan Prasarana Sosial Ekonomi}

wilayah ini memiliki satu pasar dengan frekuensi operasi satu kali seminggu dan berlokasi di Kelurahan. Selain itu juga terdapat empat SD, tiga SMP , 8 mesjid, 11 langgar, satu puskesmas pembantu, tiga bidan desa dan terdapat satu posyandu, tetapi belum ada kelembagaan ekonomi formal lainnya seperti bank.

Gambaran Status Sosial Petani

a.Tingkat Pendidikan Petani (Lampiran 6) 
Tingkat pendidikan mempengaruhi reaksi seseorang terhadap lingkungan dan akan berpengaruh pada pola pikir dan orientasi yang bersangkutan. Semakin tinggi pendidikan seseorang akan melengkapi pola pikir dalam cara memperluas wawasan melalui pemanfaatan sumber informasi yang tersedia.

\section{Tabel 7}

\begin{tabular}{|c|c|c|c|}
\hline \multicolumn{4}{|c|}{ kat Pendidikan Tahun 2016} \\
\hline No & $\begin{array}{c}\text { Jenjang } \\
\text { Pendidikan }\end{array}$ & $\begin{array}{l}\text { Frekwensi } \\
\text { (orang) }\end{array}$ & $\begin{array}{c}\text { Persentase } \\
(\%)\end{array}$ \\
\hline 1 & SD & 26 & 63 \\
\hline 2 & SLTP & 11 & 27 \\
\hline 3 & SLTA & 4 & 10 \\
\hline & & 41 & 100 \\
\hline
\end{tabular}

Tabel 7 menggambarkan bahwa status sosial pendidikan yang berkategori rendah(di bawah SLTP ) lebih banyak dibanding kategori status sosial pendidikan tinggi (di atas SLTP). Hal ini dikhawatirkan rendahnya kemampuan dalam pemanfaatan sistem informasi berteknologi tinggi yang memerlukan keahlian khusus dalam operasionalisasinya seperti internet dan perangkatnya.

b. Luas lahan garapan (Lampiran 7)

Kisaran luas lahan garapan adalah 25-50 tumbuk (2500-5000 $\left.\mathrm{m}^{2}\right)$ dan didominasi oleh kategori status kepemilikan lahan "rendah" (Luas < rata-rata $\left(33,4\right.$ tumbuk $\left.\left(3340 \mathrm{~m}^{2}\right)\right)$. Dalam hal ini tercatat 27 petani $(66 \%)$ memiliki kategori luas lahan garapan"rendah" Sedangkan sisanya 14 petani $(34 \%)$ memiliki kategori status sosial luas lahan "tinggi" yaitu dengan luas lahan garapan di atas rata-rata yaitu $40-50$ tumbuk $\left(4000-5000 \mathrm{~m}^{2}\right)$. Sebagai informasi tercatat bahwa status lahan yang petani adalah menyewa dengan ketentuan petani yang membayar pajak lahan tahunan.

\section{c. Kedudukan seseorang dalam masyarakat (Lampiran 8)}

Kedudukan seseorang menentukan jenis sumber informasi yang digunakan. Dari 41 petani hanya tiga orang $(7,3 \%)$ yang berkedudukan sebagai tokoh pemuka khususnya dalam kelompok taninya, yaitu masing-masing sebagai ketua, sekretaris dan bendahara kelompok tani sedangkan 38 petani $(92,7 \%)$ lainnya berkedudukan sebagai anggota kelompok tani. Berdasarkan data tersebut maka kedudukan petani yang berkategori "tinggi" hanya tiga petani dan kategori "rendah"sebanyak 38 petani. Ke-tiganya menjadi tumpuan bagi anggota dalam mengendalikan kelompok taninya sehingga dapat berfungsi dengan baik.

\section{Gambaran Sumber Informasi yang Dimanfaatkan oleh Petani}

Sumber informasi dalam hal ini dibedakan menjadi tiga jenis sumber yaitu lisan, tulisan dan media elektronik. Hasil analisis data menunjukkan bahwa $100 \%$ petani menggunakan sumber informasi baik secara lisan maupun tulisan, baik dari lingkungan intern keluarga maupun dari luar keluarga. Dalam hal ini informasi lisan didapat dari tetangga, pedagang, konsultan dan penyuluh pertanian serta ketua kelompok tani. Dalam hal ini sebesar 59\% (24 orang petani) menggunakan sumber informasi lebih dari lima jenis yaitu lisan (pedagang, konsultan dan penyuluh pertanian serta ketua kelompok tani), tulisan (Koran dan tulisan ilmiah) 
dan alat ellektronik (televisi dan jaringan internet) sehingga dikategorikan "tinggi". Sedangkan sisanya 41\% (17 orang) menggunakan semua sarana kecuali jaringan internet dan dikategorikan "rendah". Hasil tabulasi menunjukkan sebanyak 16 petani belum menggunakan fasilitas internet.

Hubungan antara Status Sosial dengan Sumber Informasi yang Dimanfaatkan oleh Petani

Dalam penelitian terdapat tiga status sosial yang dikaji kaitannya yaitu : Pendidikan petani, Luas lahan garapan dan kedudukan dalam masyarakat.

\section{a. Hubungan antara (Pendidikan petani) dengan Sumber Informasi yang}

Dimanfaatkan oleh Petani.

Pendidikan merupakan salah satu faktor yang berperan dalam menentukan pola pikir seseorang sebagaimana Fuad Baali (1989), secara garis besar menyatakan bahwa terbentuknya pola pikir (thought style) manusia dipengaruhi oleh tiga faktor utama yaitu: (1) Kultur, (2) Kedudukan sosial, dan (3) Kecenderungan personal. Dalam hal ini penulis cenderung menambah satu faktor lagi menjadi yang keempat, yang juga tidak bisa dikesampingkan yaitu (4) Kekayaan informasi pengetahuan. Dengan demikian pola pikir yang terbentuk selanjutnya akan mengendalikan perilaku petani, termasuk langkah yang ditempuh untuk mencari informasi dan memilih sumber informasi yang dimanfaatkan. Distribusi data hubungan antara pendidikan petani dengan sumber informasi yang dimanfaatkan oleh petani dapat dilihat pada Tabel 8 .

Tabel 8

Sebaran Data Hubungan antara Pendidikan Petani dengan Sumber Informasi yang Dimanfaatkan oleh Petani

\begin{tabular}{lccc}
\hline $\begin{array}{l}\text { Kategori } \\
\text { Pendidikan }\end{array}$ & $\begin{array}{l}\text { Kategori Pemanfaatan } \\
\text { Jenis Sumber Informasi } \\
\text { Tinggi }\end{array}$ & Jumlah \\
Rendah & \\
\hline Tinggi & 4 & 11 & 15 \\
Rendah & 7 & 19 & 26 \\
Jumlah & 11 & 30 & 41 \\
\hline
\end{tabular}

Berdasarkan Tabel 8 terlihat bahwa dari 15 petani berkategori pendidikan tinggi hanya 4 orang $(0,36 \%)$ yang menggunakan sumber informasi dengan kategori tinggi, sedangkan dari 26 orang yang berkategori pendidikan rendah ada 7 orang berkategori pemanfaatan tinggi $(0,27 \%)$. Dengan demikian presentasi pemanfaatan sumber informasi tinggi dengan kategori pendidikan tinggi sedikit lebih banyak di kalangan petani dengan kategori pendidikan tinggi. Dalam hal ini kategori tinggi dalam pemanfaatan sumber informasi menggambarkan bahwa mereka menggunakan minimal lima jenis sumber informasi baik secara lisan, tulisan maupun media elektronik, untuk menghimpun segala sesuatu yang berkaitan dengan usahataninya. Ke-5 jenis sumber informasi itu adalah : tetangga sesama petani, penyuluh pertanian (PPL), pegawai dinas pertanian, majalah, televisi, dan internet.

Hasil analisis menujukkan $X_{\text {hitung }}^{2}=0,12<X_{\text {tabel }}^{2}(3,841)$ sehingga Ho diterima dan menunjukkan tidak ada kaitan antara pendidikan dengan jenis sumber informasi yang dimanfaatkan. Dalam hal ini pendidikan tinggi belum menjamin memiliki motivasi untuk memanfaatkan sumber informasi lebih 
banyak, begitu juga petani dengan pendidikan rendah belum tentu tidak memiliki keinginan yang besar untuk mencari informasi dari berbagai sumber informasi.

b. Hubungan antara Luas Lahan dengan Sumber Informasi yang Dimanfaatkan oleh Petani.

Lahan sebagai sumberdaya menentukan kuantitas hasil produksi, maka bagi petani dengan luas garapan yang lebih kecil akan lebih berkecil hati untuk mengahadapi resiko kegagalan panen, sehingga akan lebih kuat berusaha untuk keberhasilan hasil usahataninya, agar terhindar dari kegagalan. Dengan demikian mereka akan lebih banyak menghimpun informasi untuk menghindari kegagalan tersebut dengan sebanyak-banyaknya mencari informasi menggunakan berbagai cara. Hubungan antara luas lahan garapan dan pemanfaatan sumber informasi dapat ditterangkan berdasarkan Tabel 9.

\section{Tabel 9}

Sebaran Data Hubungan antara Luas Lahan Garapan Petani dengan Sumber Informasi yang Dimanfaatkan oleh Petani

\begin{tabular}{lccc}
\hline Kategori luas & \multicolumn{2}{c}{ Kategori Pemanfaatan Jenis } & \multicolumn{1}{c}{ Sumber Informasi } \\
lahan garapan & Tinggi & Rendah & Jumlah \\
\hline Tinggi & 5 & 9 & 14 \\
Rendah & 6 & 21 & 27 \\
Jumlah & 11 & 30 & 41 \\
\hline
\end{tabular}

Tabel 9 menunjukkan bahwa mayoritas kategori pemanfaatan jenis sumber informasi adalah rendah baik pada luas lahan garapan tinggi maupun rendah (masing-masing 64\% dan 77\%). Pada pemanfaatan jenis sumber informasi rendah lebih banyak terdapat pada kalangan petani dengan luas lahan garapan rendah yaitu 21 dari 30 orang (70\%). Hal ini terjadi karena mereka sudah mengandalkan pihak yang lebih tahu untuk memenuhi kebutuhan informasinya, sehingga tidak lebih banyak berupaya dalam mencari sumber informasi. Namun demikian hasil analisis menujukkan $\mathrm{X}^{2}$ hitung $=1,68<\mathrm{X}_{\text {tabel }}^{2}(3,841)$ sehingga Ho diterima dan menunjukkan tidak ada kaitan antara luas lahan garapan dengan jenis sumber informasi yang dimanfaatkan.

\section{d. Hubungan antara Status Sosial (Kedudukan petani dalam masya-rakat) dengan Sumber Informasi yang Dimanfaatkan oleh Petani.}

Kedudukan seseorang yaitu menyangkut pekerjaan seseorang sebagai pemimpin dan bukan pemimpin baik formal maupun non formal yang dipandang mempunyai pengaruh dan wewenang terhadap lingkungannya. Hasil analisis menujukkan $\mathrm{X}^{2}$ hitung $=5,26>\mathrm{X}_{\text {tabel }}^{2}(3,841)$ sehingga Ho ditolak dan menunjukkan terdapat kaitan antara kedudukan dengan jenis sumber informasi yang dimanfaatkan. Seseorang dengan kedudukannya menjadi tumpuan bagi masyarakat sebagai nara sumber. Pemuka tersebut biasanya memiliki pengetahuan yang lebih banyak dan mempunyai kemampuan serta wewenang untuk menggerakan masyarakat sekitarnya. Hal ini menunjukkan bahwa mereka lebih banyak 
Tabel 10

Sebaran Data Hubungan antara Kedudukan Petani dalam masya-rakat dengan Sumber Informasi yang Dimanfaatkan.

\begin{tabular}{|c|c|c|c|}
\hline \multirow[t]{2}{*}{$\begin{array}{c}\text { Kategori kedudukan } \\
\text { dalam masyarakat }\end{array}$} & \multicolumn{2}{|c|}{$\begin{array}{l}\text { Pemanfaatan Jenis } \\
\text { Sumber Informasi }\end{array}$} & \multirow[t]{2}{*}{ Jumlah } \\
\hline & Tinggi & Rendah & \\
\hline Tinggi & 3 & 0 & 3 \\
\hline \multirow[t]{2}{*}{ Rendah } & 8 & 30 & 38 \\
\hline & 11 & 30 & 41 \\
\hline
\end{tabular}

Tabel 10 menunjukkan bahwa hanya 7,3\% (3 dari 41 orang) petani yang memiliki kedudukan tinggi dan semuanya memiliki kategori pemanfaatan tinggi. Sedangkan petani yang berkedudukan rendah mayoritas berkategori pemanfaatan rendah ( $79 \%$ atau 30 dari 38 orang) dan hanya $21 \%$ yang berkategori pemanfaatan tinggi.

\section{KESIMPULAN DAN SARAN}

\section{Kesimpulan}

Status sosial pendidikan berkategori rendah (63\%) lebih banyak dibanding kategori tinggi. Kisaran luas lahan garapan adalah 25-50 tumbuk (2500-5000 $\left.\mathrm{m}^{2}\right)$ dan didominasi oleh kategori status kepemilikan lahan "rendah" Tercatat 27 petani $(66 \%)$ memiliki kategori status sosial luas lahan "rendah". Sedangkan sisanya 14 petani (34\%) memiliki kategori status sosial luas lahan "tinggi" Dari 41 petani hanya tiga orang $(7,3 \%)$ "tinggi" sedangkan 38 petani $(92,7 \%)$ lainnya "remdah".

Informasi lisan didapat dari tetangga, pedagang, konsultan dan penyuluh pertanian serta ketua kelompok tani. Dalam hal ini sebesar 59\% (24 orang) dikategorikan "tinggi" untuk variabel pemanfaatan sumber informasi. Sedangkan sisanya $41 \%$ (17 orang) berkategori pemanfaatan sumber informasi "rendah". Hasil tabulasi menunjukkan sebanyak 16 petani belum menggunakan fasilitas internet.

Status sosial yang berkaitan dengan pemanfaatan sumber informasi adalah kedudukan petani dalam masyarakat sedangkan status sosial tidak berkaitan dengan pendidikan dan luas lahan garapan petani.

\section{Saran}

Berhubung masih dominannya kategori pendidikan yang rendah maka disarankan agar pihak yang terkait melaksanakan sosialisasi atau pelatihan aplikasi internet yang didukung oleh bantuan sarana yang sesuai sehingga meningkatkan keterampilan dalam mengakses informasi yang dibutuhkan.

\section{DAFTAR PUSTAKA}

Haryanto, E, Suhartini, T dan Rahayu, E. 1995. Budidaya Tanaman Sawi dan Selada. Penebar Swadaya, Jakarta.

Fuad Baali \& Ali Wardi, (1989), Ibnu Khaldun dan Pola Pemikiran Islam, (terj.) Mansuruddin \& Ahmadie Thaha, Jakarta; Pustaka Firdaus, Cet. I.

Khaeruddin. 1992. Pembangunan Masyarakat Tinjauan Aspek Sosiologi, Ekonomi,dan Perencanaan. Liberty. Yogyakarta. 
Koentjaraningrat. 1990. Pengantar Ilmu Antropologi. Riena Cipta, Jakarta.

Mardikanto, T. 1990. Wanita dan Keluarga. PT. Tri Tunggal Tata Fajar. Surakarta

Purwoko, A. 1994. Jurnal Ilmiah Ilmu-Ilmu Peratanian, Bidang Ilmu-ilmu Pertanian. Perguruan Tinggi Negeri Indonesia Bagian Barat.

Rahadi. 1995. Budidaya Sayuran Dataran Rendah. Kanisius. Jakarta.

Soekanto, S. 1994. Sosiologi Suatu Pengantar. Rajawali Press. Jakarta.

Soekartawi. 1995. Analisis Usahatani. Universitas Indonesia Press. Jakarta.

Sugiyono. 2004. Statistic Non Parametris. Alfa Beta. Bandung.

Van Den Ban, A. W . dan Hs. Hawkins. 1999. Penyuluhan Pertanian. Kanisius. Yogyakarta. 